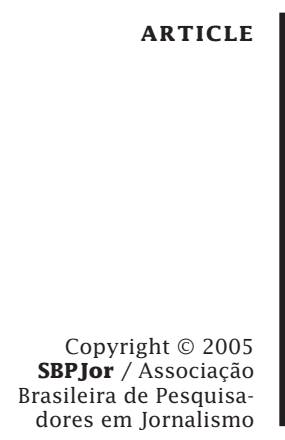

\section{THE CONSTRUCTION OF THE OTHER IN A BRAZILIAN WEEKLY MAGAZINE}

\author{
JOSÉ LUIZ AIDAR PRADO
}

Pontifícia Universidade Católica de São Paulo, Brazil

\begin{abstract}
Postmodern thought considers, in general, otherness as absolute. Bernstein (1991) denies such absoluteness, as there is always a possibility of failure in doing justice to the otherness; we should assume the responsibility of acknowledging the otherness of the Other. In this article I propose to examine the possibility of regarding the relationship between the reader and the media as ethical, that is, respecting otherness. To do so, we counterbalance the bernsteinian view with other stances, confronting communitarian authors and non-communitarian ones. What would be the meaning of the Reader's unfaithfulness in terms of a reading and communication contract? We intend to answer such questions on the basis of a thematic and discursive examination of the Brazilian weekly magazine Veja (approximately one million issues weekly), particularly analyzing how otherness is constructed in the cover stories dealing with topics such as violence and punishment, wealth and poverty.
\end{abstract}

KEY-WORDS Media; weekly magazines; discourse; violence; media education; poverty; Veja magazine.

Postmodern thinking has in general considered otherness as absolute. However, Richard Bernstein denies such absoluteness (1991:8), for he considers that there is always a possibility of failing in doing justice to the otherness of the Other. The response to such a possibility must be of an ethical nature, that is, we must assume the responsibility of acknowledging, appreciating and not violating the otherness of the Other. Habermas and Bernstein conceive rationality as "intrinsically dialogical and communicative" (BERNSTEIN, 1991: 48).

On the other hand, according to non-communitarians, we are submerged in a new constellation, assailed by the dangers of western rationality, which always reduces the different and the other to sameness by means of domination. In other words, such 
rationality does not welcome otherness, difference, or plurality. The bernsteinian response to this practical failure is ethical: we must "assume the responsibility to listen carefully, to use our linguistic, emotional, and cognitive imagination to grasp what is being expressed and said in 'alien' traditions". The question is: how do we assume this task, this responsibility?

The Other comprehends "all those concepts by means of which contemporary philosophy has sought to set out the structure of beingwith, or its original transcendental form" (BERNSTEIN, 1991: 67). But there are analyses in which the Other "is taken to be a generic term for what is excluded, repressed, suppressed or concealed" (BERNSTEIN, 1991: 68). The metaphors used to talk about the tendency of Western reason to make the Other become the Same, dominating, appropriating, controlling, mastering, as well as containing and abolishing the Other are: "imperialism", "colonization", "mastery" (BERNSTEIN, 1991: 71). Bernstein poses various theses about the otherness and singularity of the Other's otherness:

"1. The irreducible otherness of the Other "does not mean that there is nothing in common between the I and its genuine 'Other'. If there were nothing in common, we would once again find ourselves in the difficult positions of self-defeating relativism and/ or perspectivism".

2. "Acknowledging the radical otherness of 'the Other' does not mean there is no way of understanding the Other. Even an asymmetrical relation is still a relation. Alternatively we can say that to think of 'the Other' as an 'absolute Other', where this is taken to mean that there is no way whatsoever of relating the I to 'the Other', is unintelligible and incoherent. We must cultivate the type of imagination where we are at once sensitive to the sameness of 'the Other' with ourselves and the radical otherness that defies and resists reduction of 'the Other' to 'the Same' "(Idem: 74).

3. "We can never escape the real practical possibility that we will fail to do justice to the otherness of 'the Other'.

4. "But the response to the threat of this practical failure should be an ethical one - to assume the responsibility of acknowledging, appreciating and not violating the otherness of 'the Other'. Without such acknowledgement and recognition no ethic is possible. We must resist the dual temptation of either facilely assimilating the otherness of 'the Other' to what is 'the Same' or simply dismissing (or repressing) the otherness of 'the Other' as being of no significance - 'merely' contingent. We must also resist the double danger of imperialistic colonization and inauthentic exoticism when encountering 'the Other' "(idem).

5. "Learning to live with the instability of otherness; learning to accept and to encounter radical plurality which fully acknowledges 
singularity - is always fragile and precarious. (...) No one can fully anticipate the ruptures and new sites of the surging up of otherness.

(...) The search for commonalities and precise points of difference is always a task and an obligation - an Aufgabe" (BERNSTEIN, 1991:75).

I would like to pose some questions about these issues:

- Is the duty of ethics to "learn" how to accept the otherness of the Other? How does this learning take place? Who educates the educator? Who educates the Reader, the Receptor? How can researchers of media work towards doing justice to the Other's singularity?

- Must the search for the common and the different (between the I and the Other) be seen as an "obligation"? Is that the ethical imperative of Bernstein?

Respecting otherness cannot be sustained by a "must understand". Bernstein's formulas remind us of religious teachings: "resist temptation". How should we resist dual temptation? The expression "respect otherness" itself announces dead-end streets. What do we need to know about otherness in order to respect it? Is this a good way to relate to otherness (the way of duty and obligation), by not reducing the Other to the Same? And how must we consider the unconscious drives that urge us to dismantle social relationships? How could we distinguish the phantasmal Other from the Other in its radical otherness, particularly in show business, which imagines the Other in a way that turns it into something desirable, with that Freudian glow on its nose?

Our issue here is guided by the following question: do printed media (particularly weekly magazines) educate the Reader, the Receptor, to understand differences? And, on the basis of an ethics in a broader fashion, how can we think of education for a kind of media open to otherness?

On the basis of the loose speech of the patient, psychoanalysis tries to make explainable the relationship that each one has with the phantasmal Other, that is, the Other filtered through fundamental fantasy - the reduced Other. We can only be open to difference when we go through this fantasy-of-the-Other, the neurotic's Other, who with a wideopen mouth and sharp teeth asks us to give in to him as if we were objects. How is this reduced Other of the weekly magazines' middle class reader discursively constructed?

We can only open up to the Other if we can face him without feeling the fear of being devoured by him and without translating his mien into 
one of the imaginary figures through which we see the world in our particular way. This cannot be completely anticipated by means of school learning, an education that makes us able to use language and puts us in the public arena of inter-subjective dialogs.

Quite a different stance would be to think of a discursive form of presentation (or counter-discursive) deconstructing specific modes of textualizing the reality totalizing a certain relationship with the world and placing, as if it were a cork, a phantasmal Other blocking the hole of impermanence, instability and social antagonism.

Thus, the recognition of otherness cannot be achieved only through a process of identification with reference figures. Lacan emphasizes the importance of castration: the speaker might only be open to otherness if he could stand the speech "fact" of the Other. What does this mean? Firstly, the Other is not the complete figure preventing us from being Ourselves. He is faulty and his dynamic spin around the void. Secondly, the Other cannot be regarded as the guarantor of communication, of the horizon, like the symbolic fabric of phenomenological mantle culturally transforming the unknown into the known. Psychoanalysis points out the difficulty of taking the speaker to where the Other speaks. To a certain extent, Speakers, Receptors, Readers and, mainly, Enunciators of widely read/top-of-the-charts media insist on looking for a complete, complementary Other, whether it be a wise man, a winner, a hero, a celebrity, etc. - joyful/euphoric - or a mean, dangerous criminal, an antihero - joyless/non-euphoric. The powerful enunciator (the know-it-all, judge-it-all) of certain media vehicles is the homologous offset of such insistence. Thus, how can we avoid suffocating the radical otherness of the Other, how can we avoid reducing him to the neurotic's Other, economically anchored in the figure of fantasy, avoid accounting for the other in a non-democratic discourse? Within such a context, it seems innocuous to shout at the maître colonizer: Mr. dominator, stop treating the Other cruelly!

In the following lines, we will approach ethical aspects related to the reading of weekly printed media, mainly regarding the construction of otherness. Such a question will be rendered concrete by analyzing some weekly magazines' cover stories. Addressing quite homogeneous audiences in terms of socio-economic strata, weekly magazines present the Other to their readers, in such a way that the traditions of the Other are intelligible and commensurable. 
Regarding certain issues, we will try to answer the following question: how are these Others discursively constructed? We will not study texts explicitly dealing with politics, elections, but those in which the opposition I-Other permeates the construction of self-identity.

Our thematic and discursive examination of Brazilian weekly magazines (in this first study, we will restrict our analysis to Veja; in later studies we will include Época, Istoé and CartaCapital, which all together sell more than two million issues weekly) concerns the way in which otherness is constructed by cover stories dealing with the following thematic axis: violence - crime - poverty X wealth - victory - success. There are 130 cover stories out of over 1,850 weekly issues of Veja published between 1968 and 2004, whose central topic deals with the aforementioned thematic axis. The reason why we have chosen such a thematic axis is that it allows emphatic research of the opposition Same/ Other, or more specifically the Same/Victorious (or in search of Success, Victory and Wealth) versus the Other-Poor (linked to crime and violence, threatening the Same). The values of the Reader, as thought of by Veja, are placed on the side of the Same; the values that for the middle and upper class Readers constitute otherness are placed by the enunciator on the side of the Other, who threatens the Readers, makes them feel insecure and provokes them. Middle class readers are led to think of change in their country and the planet in terms of harmonizing the place of the Same within a world contaminated by an ever more intense pace of instabilities, insecurities and displacements (which Bauman, 2001, characterizes as liquid modernity). The Reader is induced to be scared of the Other.

One of the most relevant characteristics of the globalizing postmodern world is the shift from product marketing to brand marketing. In such a scenario, the relevant role played by the media is not just the capacity to inform, but also to offer cognitive maps of the world, signification maps for the readers, now consumers less sheltered in traditionally safe identity niches.

We must regard weekly magazines not just as mere transparent conveyors of ideas and information, but as publishing and enunciating brands, discursive spaces where reality is constructed, where certain reading contracts are proposed and specific communication strategies are used to construct syncretic texts (visual and verbal). Weekly magazines are like enunciating machines of identity construction providing the reader with devices for being, doing, achieving success, learning to make decisions, engaging in conversation, holding relationships, etc. Such 
devices are the homologous construction of self-help manuals brought to the realm of interpretative-informative journalism. In this sense, the weekly magazine also constructs a brand identity of a semiotic nature (a device that produces meanings), relational (the identity is constructed within a system of oppositions and relations) and inter-subjective (the brand is constructed beyond the production-reception relationship, within an inter-subjective space where endless negotiations take place) (SEMPRINI, 1995). Finally, we want to emphasize with Semprini the contractual nature of a brand: it openly proposes the establishment of a reading contract with the reader-consumer sanctioning him/her either positively or negatively. By means of these contracts and because of its semiotic nature, a brand constructs an infinite number of possible worlds (SEMPRINI, 1995: 57).

Within this broader perspective, our question will be posed as follows: How does the enunciator, playing the role of "Us", or as Landowski (2002) says, Mr. Everybody, talk about the Others; how does he construct them, those mock-Others; how relatively distant does he stand from them? How does the magazine construct the difference between us, the readers, guided by the enunciator, and the others? What is their world like? How do they get dangerously closer to our world? What can we do to avert such a danger? There is, in fact, an entire socio-cultural set of figures of the Other, from which a relative distance must be kept; an economy of differences practically useful to map the Odd and stabilize the Same. Based on the map of differences, closer or farther distances are then securely kept from those reduced Others. The latter are reduced for us by the Enunciator, who knows us and writes for us. We depend on him to be saved (or to know how we must protect ourselves), because the police and the government (sometimes more than the Others) are weak. The enunciator knows and describes for us the topology of the environment where the Others dwell.

Landowsky (2002) emphasizes this semiotic dimension regarding the production of otherness: "although the world that surrounds us spontaneously seems to be a structured and differentiated universe, there are no natural borders between 'Us' and the 'Other' - there are only the limits we construct by joining bits and pieces" (LANDOWSKY, 2002: 14). The difference established between Me and the Other is never radical or absolute, depending on the particular viewpoint (LANDOWSKY, 2002: 14). Accordingly, four grammatical configurations are established: segregation, assimilation, exclusion and admission. In the case of segregation, a faulty conjunction with the Other takes place, which does not configure 
segregation. In the case of assimilation, an opposition to exclusion takes place, where the foreigner, the Other, is welcome under certain conditions. $\mathrm{He}$ is still the Other, but assimilated. Under these conditions, the Other "can no longer be thought as a simple representative of a radically foreign elsewhere, from which, unless ordered to return (exclusion), he would have to get completely detached (compulsory assimilation); otherwise, he will to a certain degree become an integrating part of, a constitutive element of 'Us', without having to lose his identity for that reason" (LANDOWSKY, 2002: 15). This last figure is admission.

Now, let us look at some cases of the construction of otherness regarding the enunciator from Veja. Let us start with a constant subject matter in Veja, that of victory. During the 34-year existence of the magazine, 82 cover stories refer to wealth, the millions and billions earned by celebrities from different realms (sports, industry, television, religion, cyberspace), besides stories showing ways (almost self-help stories) to obtain success or earn money. In a previous analysis (PRADO, 2003:77), after examining stories about rich and successful businesspeople, we concluded that Veja maps the trends of capitalism by describing, in a somehow irreverent style, how these men think and operate, their competence being basically to earn loads of money and command the dynamics of the globalized market (such as Gates, Ellison, Welsh, etc.). Throughout the 90's and the current decade, these stories have reduced the accounts of those victors to "a non-political praise of the virtues of money earned through the globalized info-ways", without covering the issue of capitalistic by-products, such as the production of the excluded. Sheer poverty is dealt with by stories of a different kind, in an absolutely isolated manner regarding the topic of success in capitalism, as will be analyzed below. On the opposite side of the spectrum, isolated and not holding any relationship whatsoever with the aforementioned issue, there is the map of the non-winners, poverty constructed as a threat, as a crime-producing realm.

The stories about poverty, violence and crime will be divided into the following groups:

1- Cover stories in which the middle class is threatened by the poor classes or where the reaction of the middle class against the violence of the Other is portrayed, as they invest in security, weapons, etc. The middle class is depicted as squeezed and hemmed in by the Other $(6 / 6 / 84,11 / 23 / 94$, 9/25/96, 7/6/2000, 1/24/2001 etc). 
2. Stories in which the middle class is described as being the victim of the Other. The criminality rate is ever increasing. Here we can distinguish two subgroups: one in which true stories about middle-class victims of violent acts are presented, even showing their photos on the front cover $(3 / 12 / 75$, $11 / 9 / 83,7 / 24 / 91,5 / 24 / 95,8 / 21 / 96)$. There is another subgroup in which what-to-do regarding criminality is discussed. There are no references to actual victims. In this subgroup most victims do not belong to the middle class, but are poor (7/26/93). The Other here are the outlaws, kidnappers and murderers $(4 / 23 / 69,8 / 20 / 75,8 / 23 / 89,9 / 8 / 93)$.

3. Stories about the country's poverty, where violence and criminality are no longer the focus, but the problem of the Other, defined as a national problem affecting All-of-Us. The issues discussed are: hunger in the world, the reasons for poverty in Brazil, etc. (11/13/74, 1/23/2002). A sub-group also discusses individual cases of poor people in much the same fashion as in the group above. $(12 / 19 / 90)$

I will choose one or more paradigmatic story(ies) from each group as far as the magazine's discursive invariants are concerned.

Let us start with the first group. The cover story published on 1/24/2001 (fig.1), entitled "The Outskirts as a Siege" reads in the subtitle: "The middle class neighborhoods are being hemmed in by a belt of poverty and criminality that grows six times faster than the large Brazilian cities". The image on the front cover depicts the opposition between poverty, crime and social exclusion in gray (plain, monochromatic and

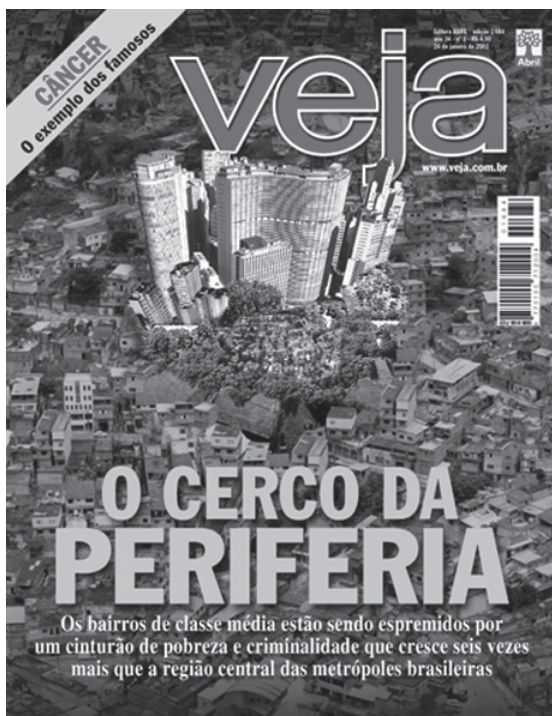
horizontal, with no high-rise buildings), suggesting dirtiness and pollution, against the central circle (colored, full of green, with well-known high-rise buildings). The front cover enunciator implies that Veja's reader is in the colored vertical area and feels threatened by the Other, the poor and criminal, monochromatic and flat, horizontal and with no perspective, who left their original dwellings (where they should remain segregated) and came too

Fig. 1. "The Outskirts as a Siege" 
close to the "well-to-do" parts of town. In the contents, the picture of a favela (Brazilian shantytown) is subtitled: "What to do with the poverty that fences in the cities". Poverty and criminality, coming from the land of the Other, fence in the cities, getting dangerously close to the "wellto-do" areas (richer neighborhoods) and therefore considered not inside the cities, threatening from the outside; thus, the poor, gathered together with the outlaws in the same group, are not regarded as legitimately belonging to the cities. They are a sort of an internal threatening Other, an invader that should stay out of the cities, stay in the outskirts. It is taken for granted that the poor should be kept segregated, as it used to be in the past. The middle class has reacted against this threat by segregating itself inside condominiums, surrounded by high walls, protected by private security guards, arming themselves and their families.

According to Veja's enunciator this process is the outcome of the accelerated urbanization that started in the 70's; Brazil did not manage to make its economy grow fast enough in order to "offer satisfactory living standards to those who have arrived". In other words, the lack of "satisfactory" wealth prevented the poor from being segregated in places adequate for them and for us, and triggered the start of the Threat. The poor are messing up and threatening the Veja readers' city. The poor could not be satisfactorily welcomed and segregated into suitable locations. The country could not produce enough wealth to segregate them in certain parts of the cities. But they came and stayed; they invaded our part of he city. The colored part of the picture in Veja's front cover is the actual town. The dark and plain part of it is the non-city invading the true city, figuratively characterizing the aforementioned insufficiency. It is the realm of the threatening and invading Other.

Another story within this group (6/6/84) bears the following front cover title "Brazilians Take up Arms" (fig.2). The subtitle in a lower case, placed above the title, completes: "Robberies, Fear and Self-defense". Inside the magazine the title goes: "With a Finger on the

Fig. 2. "Brazilians Take up Arms"

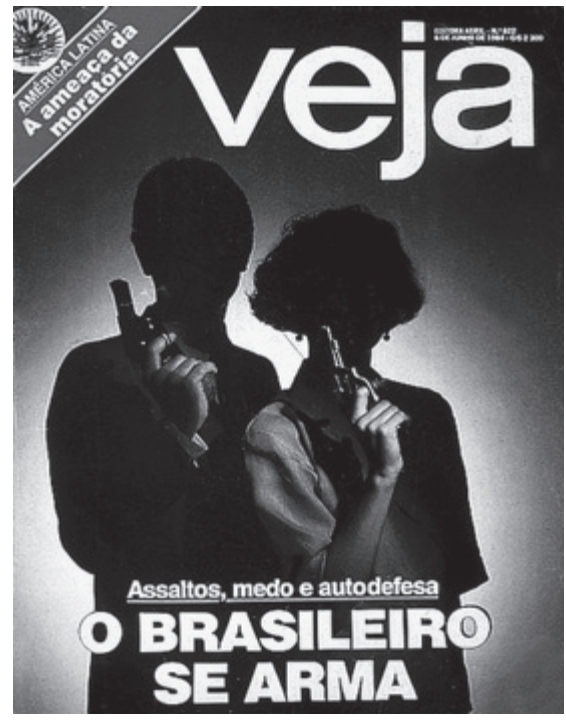


Trigger". The enunciator states: "both the robbers and the robbed know the city where they dwell, know that in Rio de Janeiro and in other large Brazilian cities, survival often depends on heavy caliber. A burglary in a building ended up in a confrontation between armed dwellers and the thieves." The enunciator states that it is only 'natural' that people take up arms to defend themselves from the Other:

"They certainly convinced a handful of Brazilians that it is necessary to take control of their own survival. In fact, keeping pace with the shocking accounts of growing criminality, a disturbing sub-product is expanding in the country, the trend towards self-defense. Citizens are increasingly acquiring weapons, installing security devices and financing what has become a true army of private guards".

Sporting gear stores decided to exchange sleeping bags for guns on their shelves. The enunciator sanctions such an attitude positively based on the criteria of 'revenue': "It was the right tactic. Last year both stores sold an average of 200 guns per month. This year this rate has gone up to 300 units a month". Veja's enunciator always has an eye on the market, on revenue increase, on the identity of players defined by having millions and billions of dollars. From what perspective is this tactic right? From the perspective of the middle class as a victim of the menacing Other, against which it must take up arms to protect itself. Veja interviews the brother of an ambassador killed in a robbery, who states: "to summarily eliminate bandits, we need to create armed militias financed by private people and deploy them around the neighborhoods under the command of sheriffs". Sources who would position themselves against weapons have no voice in this issue of the magazine.

Veja interviews Ibrahim Sued, a well-known gossip columnist from Rio de Janeiro, Brazil, who says, "it is imprudent to go about unarmed in Rio", because "there is an atmosphere of insecurity generated by an incompetent and inoperative police force". Other two voices heard by Veja are owners of two gun-manufacturing companies. The owner of Taurus, a man "in love with arms", "taught his whole family how to skillfully pull the trigger", including his two 13- and 10-year-old daughters: "Every child can be taught to shoot, as long as they are mature enough", says Fauri.

The subtitle for this part of the story is "A United Family" - the union of the family takes place around the gun protecting them against the invading Other. The assumption of the text is this: we did not manage to segregate them, so it is necessary to exclude them, kill them if necessary. We need to be ready. Veja's solution is neither democratic nor collective, 
but is individualistic, non-politicized and dangerous. Taken to extremes, this logic implies that the Other may be killed by the very hands of the Reader-victims, or by their children. The report finishes with Leda Vargas, ex-Miss Brazil, declaring that she hires armed bodyguards, but she says she cannot "come close to a weapon". The next sentence in Veja is: "Thousand of citizens used to agree with Leda, up to the very moment when they felt scared and distrustful of the police force, then they touched the trigger with their finger and found out they were ready to pull it". The middle class is depicted as "scared" and "distrustful", and so it has been led to "touch the trigger with its own fingers". This is an odd statement: touching the trigger. Either you shoot or you do not. Touching the trigger gives the impression of getting closer, getting prepared, accepting the use of the gun. The enunciator is about to shoot, but he only touches the trigger. Veja gets ready and gets the reader ready, but does not pull the trigger yet.

The magazine quotes brazilian congressman Jose Frejat's proposal for a new law that prohibits advertising the sale and/or use of arms in newspapers, magazines, radio and television, restricting such ads to specialized publications. The magazine opposes this standpoint to that of the vice president of Taurus, the gun manufacturing company, who says: "When arms get banned, only the outlaws have them". No other stances from civilian groups, NGO's, teachers and others are quoted. In order to defend themselves against the criminal Other, readers have to take up arms and tell their children to carry guns.

Because of the fear provoked by the invasion in progress, the enunciator concludes that it is necessary to take up arms. The magazine sanctions a civil war-like, antidemocratic, far-west atmosphere. Veja's world is not that of constructing citizenship. This report shows the scared Brazilians (who must defend themselves and their families), the incompetent police force, the private security guards (called a "parallel army"), the gun manufacturers and other people in favor of carrying weapons as the subject matter of the story. The enunciator states, "Brazilians take up weapons", although we know that not every Brazilian has a gun, that not all the inhabitants of the outskirts are poor and that not all the outskirts are inhabited by bandits and criminals, but this is the assumption based on the dual position described by the magazine. And despite constructing both possibilities (in favor of or against carrying arms), the enunciator is clearly in favor of readers "touching the trigger" (in order to survive). He is extremely understanding, and even stimulates the decision made by part of the scared population to take up arms. 
The thousands of Brazilians thinking like Leda resisted until they got scared and distrustful, leading them to take up arms, a fact positively sanctioned by Veja. According to the enunciator, Leda Vargas' attitude is sustainable until the violence coming from the dangerous plain gray areas of the Other gets too close. Then, the only way out is to buy a gun, transforming the world of democratic civilians into a world where the logic of the invader and the bandit legitimates the violence practiced by all. The reader can even choose a gun from an item in the magazine informing prices and features. Such is Veja's service: the reader can choose the device to summarily eliminate the Other.

At this point, it is relevant to remark that fear is the primordial passion used as the magazine's persuasion strategy. We cannot explain how the relationship with the Other is established within the reading contract proposed by the magazine without understanding how fear permeates the discursive strategies of Veja. Hernandez (2001:141) approached this issue in relation to employment and globalization as treated in Veja:

"...there is an imaginary aspect in any kind of fear, a passion related to the future. Borders between true and false dangers are also less distinct than what they seem to be. The subject received some information before starting to be corroded by his misgivings. Such recently acquired knowledge demands his awareness. Then he constructs an existential simulacrum. In the case of fear, the subject projects himself towards a particular situation, weighs his own capacity of confrontation and reaction, as well as that of his opponents and eventual partners. Greimas and Fontanille define this existential simulacrum as 'the subject's projection into a passional imagery'. More precisely, the subject had a previous simulacrum in which he imagined himself with all his capacities to maintain his value-object. Then, he enjoyed the passion of security, tranquility, a knowing-how-to-be-able-to-be. Only that the new recently acquired knowledge obliged him to update the whole scenario. When he realizes that he is desperate, or he has doubts about his capacity to confront the unexpected threat, then he is overcome by fear".

According to semiotics, there are two types of fear:

- The passion linked to the subject's perception of the lack of the demanded competence at the moment of the performance to maintain the object, or even the perception that the anti-subject has a better competence to act (HERNANDES, 2001:143).

- The fear derived from the possibility of a negative pragmatic sanction by the destinator (FIORIN, 1992:57). 
Hernandes, after analyzing the construction of globalization in Veja concludes:

"From the passional point of view, whoever accepts globalization as a destinator is afraid of punishment in case of his unsuccessful performance. Those who do not accept globalization as a source of value fear the actions of the anti-subjects destroying employment on behalf of 'the new world order': competition, informatization, new management forms, etc."

Also within the first group, a story with the front cover title "Help!" (6/7/2000, fig.3) presents a middle class family completely dressed in medieval armor. The same title is found inside with the following comment: "A murder every 13 minutes. Criminality in Brazil breaks records, terrorizes society and authorities do not manage to defeat the criminals".

According to Veja, the actions of the State are increasingly insignificant statistically, despite the increase of public investment in security. Citizens are afraid: "While the State of São Paulo was making strenuous efforts, the number of homicides grew 30\% in the State. The amount of thefts and robberies of vehicles doubled. Mass murders doubled in 1999 compared to 1998. 'Those devoting themselves to understand what happened are seriously disappointed', says Mr. Claudio Beato, professor of the Federal University of Minas Gerais and a specialist in criminality". The specialist is unaware that Brazilians are doing what they can to protect themselves. Several cases are presented: a lady lawyer who contracted a guard, buildings where security systems are being installed, etc. The passional nature of the account is built up, featuring scared citizenReaders and their disappointment due to the ever-increasing power of the outlaws versus the weakness of the police and the inefficiency of the State.

Within the second group of stories, concrete cases are told with photos of victims of the

Fig. 3. "Help!"

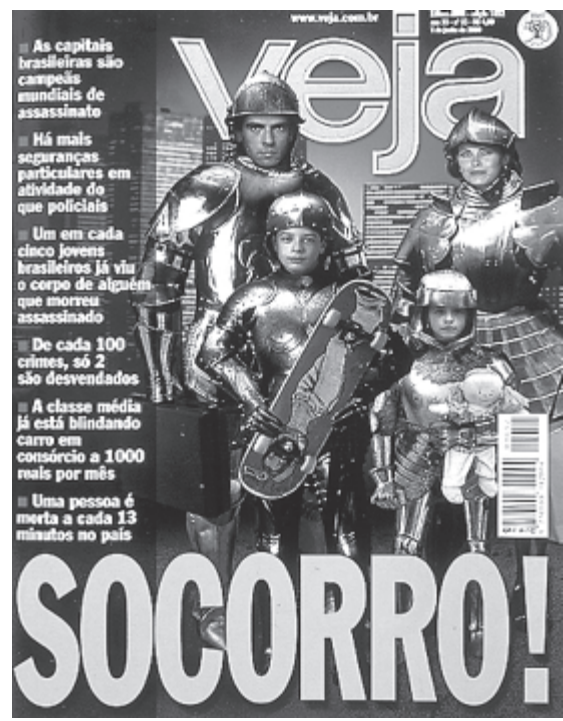






Fig. 4. "Nobody Looks after the Victims"

criminal-Other. In the $11 / 9 / 1983$ issue (fig.4), mother and daughter appear on the front cover under the title: "Nobody Looks after the Victims", and the subtitle: "Laura Tomé Tomarevski, 23, and her daughter Talita, 8 months, assassinated in São Caetano (SP) during a robbery". The inside title is "The Victims' Hell". The subtitle: "Tragedy in São Caetano shocks and awakes the nation". The enunciator tells us how the crime was committed during a bank robbery and ends the first part of the story with the following sentence: "Talita's and Laura's tragedy shocks the entire nation. It is at the top of the ever-increasing violence in Brazilian cities". São Paulo and Rio de Janeiro "have been ranked for the last few years among the most violent and insecure cities in the world". The story reports the reactions of Laura's relatives and the robbers' tale.

Subsequently, the enunciator reads that "as fear spreads out in the streets", governor Franco Montoro speaks on a radio and TV network "declaring war against crime and violence". The next issue reports: "in Brazil there is no single organization to socially shelter or compensate financially the victims of crime". The next opposition to be constructed by Veja is the one of Yeda, the mother of a murdered young lady, who organizes an association to aid victims of violence and criticizes the organizations "that sponsor the rehabilitation of criminals". Yeda, characterized in the report as being "catholic and liberal", defends the "right of criminals to rehabilitation programs, but only those who have not commited murder". She says, "Because assassins cannot be rehabilitated, the death penalty should be instituted in order to diminish criminality in Brazil". The enunciator knows all the conservative arguments in favor of the death penalty, but does not position himself clearly either for or against it. He remains in the shadow, but just at the border line, almost agreeing with the defenders of the penalty as they keep their fingers touching the triggers. All in all, there are five items with tales about the victims' and the assassins' relatives, including photos of both. 
A retired lady voices her complaint about Dom Paulo Evaristo Arns, the Catholic Archbishop of São Paulo, Brazil, saying that he practices "demagogy when defending criminals". Veja stands at the side of victims" families insisting that while the State takes care of the rehabilitation of criminals, it never looks after the families of the victims: "The State will employ social workers to take care of prisoners, but there is no concern for looking after people like José Veloso and Dona Cordélia". Veja's stance is that investments are aimed at the rehabilitation of criminals, but not at aiding the families of victims.

The enunciator interviews the victims' relatives defending the death penalty and concludes: "inside the circle of victims of crime, defense of the death penalty conquers supporters at a fast pace". A congressman from PTB (the acronym of a right-wing political party) is quoted as endorsing in Congress "an amendment to the Brazilian Constitution applying capital punishment to recurring criminals who commit armed robbery or theft followed by rape". Subsequently the magazine quotes the opposite stance by the president of the Criminal Court, who does not believe that "the death penalty is the best means to reduce violence. If that were the case, violent crime would not exist in the United States where capital punishment exists in many of the States". At the end of the report, Laura Tomarevski's husband is quoted in a positive sanction, as having "the most sensible position". Says the husband: "I think that those sentenced must undergo a process of regeneration". In spite of this last statement, the enunciator does not oppose the death penalty at any time, as mentioned above, creating a performative paradox. The enunciator, with a finger on the trigger, insists on the fact that the approval of the death penalty is on the increase, nearly agreeing with the stances favorable to capital punishment, and almost stating that criminals should not be supported or rehabilitated, but finally showing some sensitivity by identifying with Tomarevski's husband, who visited some inmates in a penitentiary trying to "convince them of the need to live according to religion". The enunciator stands among the plurality of opinions, stuck in the adhesive side of the conservative discourse, but makes up his mind about "letting it be". Thus, he walks in a spiral, somehow supporting the opinions of the most conservative readers, and, on the other hand, not standing openly in favor of the most rigid stances within society.

That spiraled strategy, discursively balanced, does not make the enunciator less strong or less decisive at all. Despite the excesses mentioned, the enunciator puts on airs of being a "democratic but 
prudent" magazine, closing up the spiraled text in a fashion showing it as "balanced".

Other cover stories follow the same structure, as is the case of those published on 7/24/1991,5/24/995 and 8/21/1996. In general, the enunciator constructs the narration based on the readers' feeling of insecurity, because they live "in a city with unpunished gangs and an inefficient police department", and describes kidnappings and crimes committed against the middle and upper classes.

In the third group of articles the magazine regards poverty as a national problem.

In the story published on 12/19/1990 under the cover title "The very poor - there has never been so many people living in the streets", and with the inside title "The problem of Brazil", the enunciator narrates the confrontation between invaders of an unoccupied piece of land in Diadema (a city near São Paulo, Brazil) and the Military Police. Two thousand families "decided to obtain a roof over their heads by using an ever more popular instrument in the real estate market of the very poor - the invasion of an empty lot..." (the italics are mine, to show the ironic expression). The landowner filed suit for repossession of the lot and "400 soldiers of the Military Police were deployed to Diadema to guarantee the enforcement of the law". After describing the outcome of the conflict with casualties, wounded people and huts and shacks knocked down by tractors, the enunciator states:

"Brazilians of the 90's, welcome to one of the descamisados' (the shirtless, meaning the destitute, N. of A.) most fashionable show in this country. Last week it went on in Diadema, with explicitly violent scenes, but it can be seen every day, at any time and with no long waiting lines, in any big city of the country. Worst of all is that to see the show you do not even need to drop by a favela (shantytown), a cortiço (slum tenement) or an invaded property, You just have to look at the sidewalks, under bridges and other public places, and there you will see the actors - people who live in the streets in ever increasing numbers, poor to the extreme of being unable to dwell in a favela, and who are not just seen as an aesthetic discomfort any longer, but have become one of the most terrible condemnations of the social 'apartheid' established in Brazil'.

The irony of this selection of text is impolite. To call such poverty a fashionable show, associating violence with extreme poverty, is sheer cynicism. Ambiguity makes us read the text as if the enunciator was saying: "look at this absurd show", look at the ridiculous place we 
live in. Only irony is left. However, this artifice also has a caustic side: together with the presumably permissible irony, the enunciator releases his 'truth', expressing his rage at the shirtless Other, starring a ridiculous 'show' of bad taste, an 'aesthetic discomfort'. Walking along the razor's edge, assuming again the spiral path, the enunciator almost collapses from a minimum level of ethical enunciation and manages to get away with it in the last part of the text: we experience this reality of "terrible condemnations of the social apartheid established in Brazil". There is, so to speak, a short circuit between expression and content, revealing the conservative ideological position of the magazine.

Next, the increase in the number of such invasions in different Brazilian cities is covered. The issue featured by Veja is the following:

"Brazilian society is organized so as to render its (the tragedy's) repetition inevitable. As it is widely known, that part of the Brazilian elite that thinks, decides, and exerts influence, has engaged in lengthy discussions on different issues. In the past, the discussion had centered on what would be the best economic model for our country. Later, the debates contemplated what should be done with the Constitution. In 1989, the country had its first direct presidential elections in thirty years. Recently, businessmen, union leaders and ministers gathered to debate what they call the social pact".

The real problem that Brazil should discuss, however, is called extreme poverty, involving 60 million citizens who have no homes, no schools for their children, and no hope. It is a larger population than that of France and South Korea, equivalent to twice that of Argentina. This is the real problem, from which episodes such as the one in Diadema result. And it is precisely because of this problem that we have ever more people living on the streets. Perhaps at no other time before now has there been such extreme poverty so massively visible in the daily life of the country.

Subsequently, Veja publishes another article called "Street Citizens", saying in a subsection: "With a ruthlessness that has never been seen before in Brazilian history, extreme poverty shows its face in the large cities of our country."

In this article, the enunciator quotes street dwellers that explain why they have arrived at this predicament of not having a roof over their heads. The author says:

"There was a time when sleeping on the streets had a bohemian or even poetic quality to it, as Noel Rosa said in his song: My bed is a newspaper page. In the past, people who lived in Brazilian streets 
were the ones that you would expect, the destitute - beggars, alcoholics, the unemployed and the waifs and strays. The difference is that today there are other types of people struggling to dwell in the same streets. They are unemployed workers, poor small farmers who have decided to try their luck in the big city because their fields have dried up, retired people, mistreated by scanty welfare payments and, worst of all, workers whose wages are no longer even sufficient to rent a shack in a favela (shantytown), nor to afford a room in a cortiço (slum tenement)".

For Veja this is nothing new: "For at least two decades it has been possible to foretell that a social disaster of epic proportions would arise in Brazil, a direct outcome of political decisions and measures dictated by the government or by those sections of society that influence the guidelines of these policies that grossly excluded most Brazilians from the benefits of development".

An opinion heeded by Veja is that of urban planner Suzana Pasternak Tashner, from USP (University of São Paulo), who states: "Urban poverty is leaving the outskirts for the downtown districts, reflecting the end of a period, the era of owning a house". The problem is no longer just constructing housing complexes, because "even if there were enough houses, the beneficiaries are so extremely poor that they would not have the financial capability of living in them".

What "calls our attention", says the enunciator, in the Brazilian case, is that the country has the capability to develop and at the same time is incapable of providing a better fate for the homeless.

"Furthermore, over the last few decades Brazil has only been able to grow by producing an ever-increasing number of extremely poor people. This is a perverse item of data regarding the Brazilian development system, that the 350-billon-dollar GNP - fourteen times bigger than thirty years ago - has no impact whatsoever on the lives of such a vast number of citizens. During a very long time, the existence of the very poor was explained by the fact that there is always some pain in growing, or by the need for impoverishing part of the people in certain phases of development. What is clear today is that the socially outcast are the outcome of the social savagery practiced during the most part of our development. In its current phase, the Brazilian social tidal wave has undergone an even more dramatic change".

Such simultaneous capability and incapability make up a sort of deadlock. In spite of advances, the strata of poverty-stricken people remain. For Veja, extreme poverty is a paradox; whereas wealth is not. Veja's strategy is to embrace conservatism while seemingly maintaining 
a certain open-mindedness and concern regarding the poor, assuming an air of social tactfulness regarding the hardships of the poverty-stricken Other, as long as that Other does not invade the colored and wealthy heart of our cities. Let the Other remain there, where they belong.

The cover story on 1/23/2002 takes up this issue again: "Poverty - the Great Challenge of Brazil" - and the comment: "The 23 million poverty-stricken Brazilians cannot be ignored any longer". In the contents, below a photo of some poor people bathing themselves with a bowl, we read: "Despite advances, the poverty-stricken strata persist". Poverty is everybody's, but wealth belongs to just a few, the strugglers, the competent ones in the midst of social Darwinism.

Poverty is inexplicable and causes pain in our hearts, but wealth is entirely explicable: it is necessary to be strong (according to the cover story on Abílio Diniz, the Brazilian supermarket tycoon). Misery belongs to the Other, but it becomes dangerous when the police and the government let it infiltrate the pulsating heart of our city, that is, Veja readers' city. The Other deserves our charity, our attention, but when they get too close, they become a threat. It is necessary to keep them at a distance. This, and no other, is the synthesis of Veja's strategies and concerns. It is only in this sense that the magazine states that poverty is everybody's problem.

Within a truly democratic process, it would be the case to say: poverty is indeed everybody's problem, in the sense that all of us have to struggle collectively against it. But such thing does not actually happen. If the Others do get closer and the police cannot stop them, the middle class and the rich will take up arms, will organize their armies, will touch the trigger, will invest in eliminating and imprisoning the Other. The inside title of the story is "The Paradox of Poverty". A comment explains what that paradox is: "Brazil is the richest nation among those with the largest number of poor people. This makes the extreme poverty suffered by 23 million Brazilians inexplicable. Nonetheless, it also shows that the problem could be successfully tackled". All photographs are in a monochromatic black and white and the boxes are gray reticulations.

According to the enunciator:

"...poverty in Brazil consists of components more perverse than the mere scarcity of resources - which is the main characteristic of the problem in other countries, particularly in Africa. We refer to two great paradoxes. The first one is that in poverty-stricken Brazil there is a huge surplus of food. (...) The second paradox is that never before so much money has been spent on social programs 
and even so, the painful situation of the very poor has not improved a bit. Municipal, state and federal governments collect in the form of taxes, tariffs and contributions a total amount equivalent to $34 \%$ of the GNP. Out of every 10 tax dollars collected, 6 are spent on social programs. No other country in South America spends that much."

Subsequently, the magazine praises Comunidade Solidaria, a social program commanded by the First Lady. Why is it that all these efforts are not enough "to make social indexes improve"? Answers: 1) "specialists say that the poverty rate will begin to drop as soon as the economy starts growing fast again". Other countries have been able to overcome the problem, such as Hong Kong, Taiwan and South Korea: they invested heavily in education, health care and agrarian reform. However, Veja never takes up those issues in its cover stories; it would rather emphasize fear as an issue and solutions that are the outcome of fear. In Brazil funds are badly distributed, says Veja. Educational funds go to state universities, which educate the very rich; health care funds go to curing the sick and not to promoting preventive medicine, and very little is invested in sanitation. Funds are used inadequately and it is necessary to dismantle the mechanisms that concentrate income in only a few hands.

There are other ethical aspects involved within the relationship Media-Reader that we will study in another article. Our main issue here is: What does printed weekly media say about the Other? It is also necessary to think about the enunciating identity of the reader on the basis of the figure of unfaithfulness.

In terms of educating the media, we defend the idea of the reader being led to study the ways in which the Other is constructed by the media. The reader can only open up to otherness provided he/she realizes the relative enclosure in which the media constructs the Other. Only by being aware of this scenario will readers probably realize the dictatorship of their own Sameness portrayed in the media, with which they somehow identify. The reading ethic herein contained proposes the need for teaching future readers, as for example high school and college students, to compare texts, studying how discursive strategies construct the image of the Other. This is the reason why we propose to set the objective of educating readers to be unfaithful to a single vehicle, an exclusive consumption product, a media of narcissistic identification.

Moreover, our future Reader must learn to identify the Total Enunciator. The Faithful Reader is the counterpart of the Total Enunciator, who presents the Other as reduced to sameness. The Total Enunciator constructs issues 
and avoids listening to the diversity of social voices, and he does not define the democratic society on the basis of its antagonisms. On the contrary, he hides antagonisms. It is necessary to educate a reader who will not need an all-certain, self-assured, know-it-all enunciator a reader who will wish to think freely for the sake of autonomy. Such a reader will certainly reject a totalizing, omniscient and supposedly All-knowing enunciator, and will assume the freedom of thinking independently (such a discourse on the unfaithful reader could be based on the analyst's discourse, on LACAN:1992). The unfaithful reader will be able to open his eyes to the broad multiplicity of enunciating strategies and the constructive/discursive "reality", not on the basis of passions such as fear, but based on systems of plurality and democratic diversity. Only in this perspective can we think of an ethical reading contract, agreed upon within the communicative process of mediatic production.

Note: This text was originally presented at the congress of IAMCR 2004 (International Association of Media Research), in the Ethics of Society, Ethics of Communication Working Group.

\section{BIBLIOGRAPHY}

ANDRADE, M.L.C.V.O. A revista Veja: interação e ensaio. SP, Humanitas, 2002.

ARBEX Jr. , J. Showrnalismo: a notícia como espetáculo. SP, Casa Amarela, 2001.

BAITZ, R. Um continente em foco: a imagem fotográfica da América Latina nas revistas semanais. SP, Humanitas, 2003.

BARROS, D.L. P. Teoria semiótica do texto. São Paulo, Ática, 1990.

"Paixões e apaixonados: exame semiótico de alguns percursos", Cruzeiro Semiótico, 11-12. Lisboa: Associação Portuguesa de Semiótica, 1989.

BAUMAN, Z. Modernidade líquida. RJ, Jorge Zahar, 2001.

BENEVIDES, M.V. Violência, povo e polícia: violência urbana no noticiário da imprensa. SP, Brasiliense, 1983.

BERNSTEIN, R. The new constellation. Cambridge, Polity Press, 1991.

BOURDIEU, P. A economia das trocas linguísticas. São Paulo, Edusp, 1996. 
BRAUDEL, F. La dinámica del capitalismo. Cidade do México, Fondo de Cultura, 1986.

BUCCI, E. Sobre ética e imprensa. SP, Cia das Letras, 2000.

CAPELATO, M. H. Imprensa e história do Brasil. São Paulo, Contexto, 1994.

CONTI, M.S. Notícias do planalto. São Paulo, Cia das Letras, 1999.

DERRIDA, J. Espectros de Marx. Rio de Janeiro, Relume-Dumará, 1994.

DUSSEL, E. O encobrimento do Outro. Petrópolis, Vozes, 1993.

FAIRCLOUGH, N. Discurso e mudança social. Brasília, UnB, 2001.

FARO, J. S. Revista Realidade 1996-1968. Porto Alegre, AGE, 1999.

FAUSTO NETO, A. Comunicação e mídia impressa. São Paulo: Hacker, 1999.

Mortes em derrapagens: os casos Corona e Cazuza no discurso da comunicação de massa. Rio de Janeiro: Rio Fundo, 1995.

FIORIN, J.L. Lições de texto. 4a edição. São Paulo, Ática, 1999.

. Elementos de análise do discurso. São Paulo: Contexto, 1997.

. "Algumas considerações sobre o medo e a vergonha". In:

Cruzeiro Semiótico, n 16, janeiro 1992. Associação Portuguesa de Semiótica.

GREIMAS, A J. e FONTANILLE, J. Semiótica das paixões. SP, Ática, 1992.

HABERMAS, J. Pensamiento postmetafísico. Madri, Taurus, 1990.

1989.

El discurso filosófico de la modernidad. Madri, Taurus,

HERNANDES, N. "A revista Veja e o discurso do emprego na globalização".

Dissertação de Mestrado, FFLCH-USP, 2001.

LACAN, J. O Seminário 7. A ética da psicanálise. Rio de Janeiro, Jorge Zahar, 1988.

O Seminário 17. O avesso da psicanálise. Rio de Janeiro, Jorge Zahar, 1992.

Écrits. Paris, Seuil, 1966.

LANDOWSKI, E. Presenças do Outro. SP, Perspectiva, 2002. A sociedade refletida. São Paulo, Educ/Pontes, 1992.

MENDONÇA, K. "Assentamento da memória: (re)construções de memória discursiva na revista Veja”. SP, CD Compos, 2004.

MIRA, M. C. O leitor e a banca de revistas. São Paulo, Olho dágua/Fapesp, 2001.

MOUFFE C. The return of the political. London: Verso, 1997.

PINTO, M. J. Comunicação e discurso. São Paulo: Hacker, 1999. 
PRADO, J. L. A. "O perfil dos vencedores em Veja". In: Revista Fronteiras, Vol. V, n’2. São Leopoldo, Unisinos, dezembro 2003, pp.77.

"A construção da violência em Veja". In: DeSignis, vol. 1, n 2, abril 2002. Barcelona, Gedisa, p. 259-272.

Hacker, 1996.

RORTY, R. Consequences of pragmatism. 4a.ed. Minneapolis, University of Minesota Press, 1989.

SEMPRINI, A. El marketing de la marca. Barcelona, Paidós, 1995.

TORFING, J. New theories of discourse. Oxford, Blackwell, 1999.

ZIZEK, S. Estudios culturales: reflexiones sobre el multiculturalismo. Buenos Aires, Paidós, 1998.

José Luiz Aidar Prado is the coordinator and Ph.D. professor of the Postgraduate Program in Communication and Semiotics at PUC-SP (Pontifical Catholic University of São Paulo), Brazil. He graduated from USP (State University of São Paulo), Brazil, with a Bachelor of Philosophy degree. He was vice president of the National Postgraduate Program on Communication - Compós (1999-2001). He is the author of Brecha na Comunicação (Communication Breach) and co-author and organizer of Lugar Global Lugar Nenhum (Global Place No Place) and Crítica das Práticas Midiáticas (Critique of Media Practices), among others. E-mail: zupra@terra.com.br 
